\title{
Investigating Effects of Metacognitive Strategies on Reading Engagement: Managing Globalized Education
}

\author{
Naihean HUO ${ }^{1}$, Yooncheong $\mathrm{CHO}^{2}$
}

Received: March 31, 2020. Revised: April 30, 2020. Accepted: May 05, 2020.

\begin{abstract}
Purpose: Previous studies rarely investigated the effects of the metacognitive reading strategies on reading engagement, particularly in globalized higher education, while those studies examined reading problems and engagement with lower reading level. The purpose of this study is to investigate the effects of the metacognitive reading strategies including global reading, problem solving, and supporting reading on reading engagement that include argentic, behavior, emotional, and cognitive engagement in global learning environment. This study investigated research questions: how do global reading, problem solving, and supporting reading strategies affect argentic, behavior, emotional, and cognitive reading engagement? Research design, Data, and methodology: This study collected data via online survey in globalized learning environment. This study applied statistical analyses, such as factor and regression analyses and ANOVA. Results: The results of this study showed that metacognitive reading strategies had significant effects on student reading engagement while they were reading class materials in English for academic purposes. Conclusions: This study provides managerial implications in higher education by providing better strategies to enhance learning skills in global context. In particular, this study provides implications that the effects of problem solving and supporting strategies could be improved by adopting better management systems in globalized education.
\end{abstract}

Keywords: Metacognitive Strategies, Reading Engagement, Globalized Education.

JEL Classification Code: I23, P23, F01

\section{Introduction}

Global learning has been addressed as essential to higher education and what global learning provides for teaching, learning, and internationalization have been examined (Kahn \& Agnew, 2017). English, in globalized learning environment, is being used worldwide as the global language (Seidlhofer, 2005) and has played a crucial role. To improve communication, English language learners have required four macro skills to include reading, listening, speaking, and writing (Aydogan \& Akbarov, 2014). Among the four macro skills, reading skills are considered the main doorway to knowledge (Shehadeh, 2016). Previous studies

1 Graduate, KDI School of Public Policy and Management: Email: naihean.huo@gmail.com

2 Corresponding Author: Professor, KDI School of Public Policy and Management, Email: ycho@kdischool.ac.kr

(c) Copyright: The Author(s)

This is an Open Access article distributed under the terms of the Creative Commons Attribution Non-Commercial License (https://creativecommons.org/licenses/by-nc/4.0/) which permits unrestricted non-commercial use, distribution, and reproduction in any medium, provided the original work is properly cited.
(Amin, 2019; Madhumathi \& Ghosh, 2012) also stated that reading played a significant role in education.

Therefore, reading can help learners succeed in an academic setting. Amin (2019) stated that reading was considered as one of the most challenging areas, which required more attention in any education (p. 35). As studied by previous researchers, English as a Foreign Language (i.e., EFL) and English as a Second Language (i.e., ESL) learners face many challenges from secondary school through postgraduate education due to the lack of academic vocabularies, reading fluency/proficiency, background knowledge, and reading skills for academic purposes; therefore, readers require lots of inferencing and a set of reading strategies when reading becomes difficult (Grabe \& Zhang, 2013). As Nezami (2012) identified, readers often face the same common reading problems such as insufficient comprehension, because they do not know how to read effectively by using reading strategies, which leads to their poor performance in both their academic and working lives. 
To overcome reading challenges, reading strategies are necessary to help readers comprehend the reading texts and must be effective to readers, otherwise they still have difficulties in reading English academic texts (Hamza \& Nur, 2018). Improving engagement in reading is also significant to enhance students' reading comprehension (Guthrie \& Klauda, 2014). Reading strategies have been highly recommended by many previous researchers to strengthen learners' reading comprehension and competencies (Shehadeh, 2016). According to Pinninti (2016), reading strategies are defined as "deliberate, goaldirected actions to understand and construct meanings of a text" (p.179), or as specific techniques that help readers complete their reading tasks successfully. Reading strategies are commonly used by readers from English and non-English speaking countries while reading English for academic purposes (Mokhtari \& Reichard, 2004; Sheorey $\&$ Mokhtari, 2001). In this process, readers apply reading strategies and other knowledge to comprehend the meaning of the texts and to engage their learning (Songsiengchai, 2010). Reading strategies can be employed based on the readers' awareness that is suitable for their knowledge while reading the texts (Alfassi, 2004). In this view, readers use different strategies from one another (Ilustre, 2011) and, as emphasized by Alderson (2000), good readers are flexible in their personal reading strategies, and their ability to comprehend the texts is significantly dependent on the strategies they use while reading.

While there are numerous reading strategies discussed by previous researchers, this study will examine the metacognitive reading strategies that consist of global reading, problem solving, and supporting reading strategies (Mokhtari \& Sheorey, 2002) and help readers know what, when, where, and how strategies are used while reading English academic texts (Karbalaei, 2010). By adopting metacognitive reading strategies, readers have different awareness of choosing suitable reading strategies that can help them when reading for academic purposes (Karbalaei, 2010; Mokhtari \& Reichard, 2004; Sheorey \& Mokhtari, 2001). The purpose of this study is to investigate the effects of the metacognitive reading strategies in global education environment, while reading texts in English for academic purposes. This study also applied reading engagement that includes argentic, behavior, emotional, and cognitive engagement. Previous studies rarely examined the effects of metacognitive reading strategies on reading engagement in higher education and also in global academic context. Therefore, the purpose of this paper will fill the gap to explore how metacognitive reading strategies used by students who are studying in a global academic environment, affect their reading engagement while reading English scholarly texts. By applying three different categories of metacognitive strategies including global reading, problem solving, and supporting reading strategies, this study proposed following research questions: i) how do cognitive reading, problem solving, and supporting reading strategies affect student agentic reading engagement? ii) how do cognitive reading, problem solving, and supporting reading strategies of metacognitive reading strategies affect student behavioral reading engagement? iii) how do cognitive reading, problem solving, and supporting reading strategies of metacognitive reading strategies affect student emotional reading engagement? and iv) how do different categories of metacognitive reading strategies affect student cognitive reading engagement?

\section{Literature Review}

\subsection{Metacognitive Reading Strategies}

Papleontiou-louca (2003) explained metacognition as cognition about thought about thought, knowledge about knowledge, and reflections about actions and addressed that metacognition involved thinking about one's perceiving understanding, remembering, etc. Carrell, Pharis, and Liberto (1989) addressed that metacognition was how readers understood the cognitive process, which involved two types of cognition in the reading context including leader's knowledge of strategies for learning and control leader's actions while reading for different purposes. Jacobs and Paris (1987) classified metacognition in reading into two parts such as self-appraisal of cognition for static assessment and self-management of thinking for dynamic aspect of translating knowledge into action. ELS/EFL reading strategies are divided into categories including cognitive deliberative actions taken by readers, metacognitive advanced techniques, and supporting strategies to help understanding (Sheorey \& Mokhtari, 2001). Metacognitive reading strategies are defined as methods that allow readers to think about what they are reading, which help them understand the way they learn (Mukhlif \& Amir, 2017). Karbalaei (2010) stated that metacognitive reading strategies referred to metacognitive awareness that readers understood what to do with their duties of reading and metacognitive regulation or control readers to understood how and when to practice reading techniques while reading texts. For instance, readers have reading purposes, preview and check if the texts align with those purposes, determine what to read or ignore (metacognitive awareness), make predictions or guess the text's meaning, check dictionaries, re-read (metacognitive regulation or control), and other reading methods (Sheorey \& Mokhtari, 2001). Therefore, metacognitive reading strategies allow readers to use any cognitive strategy to overcome their reading problems in order to support their 
reading comprehension. The metacognitive reading strategies are also classified into global reading, problem solving, and supporting reading strategies (Mokhtari \& Reichard, 2002).

Previous studies have found that all readers use metacognitive reading strategies while reading English texts for educational reasons to understand their reading materials. Metacognitive reading strategies, particularly play a crucial role in foreign and second language reading comprehension and in EFL/ESL courses (Farahian \& Farshid, 2014) because these strategies help non-native English readers who are lacking English language proficiencies (e.g. lack of academic vocabularies) to design their own strategies that improve their learning (Grabe \& Zhang, 2013). For example, college students from Saudi Arabia who are non-native English speakers used distinct metacognitive reading strategies to moderately enhance their understanding of English academic tasks since students' reading proficiencies are still limited (Meniado, 2016). Therefore, metacognitive reading strategies are commonly used among readers who speak English as a first, second, or foreign language.

\subsubsection{Global Reading Strategies}

Strategies for global reading are the first category of metacognitive reading strategies. Mokhtari and Sheorey (2002) identified global reading strategies as intentional, carefully planned techniques monitoring their reading texts by readers. It is further explained that readers who use global reading strategies always have a purpose for reading, activate previous understanding, verify if the material suits their purposes, skim to find the related information, decide what to read, and use contextual hints, structures and other textual features to increase reading comprehension (Pookcharoen, 2009). This shows that readers who apply global reading strategies while reading English academic texts have plans for their reading tasks and try to find ways to fulfill their reading purposes.

\subsubsection{Problem Solving Strategies}

The second category of metacognitive reading strategies is problem-solving strategies. Mokhtari and Sheorey (2002) defined problem-solving strategies as actions or procedures that readers use while working directly with the text as localized, focused techniques to deal with difficulty while reading (p. 4). To diminish these difficulties, these strategies provide readers with action plans that allow them to navigate through text skillfully (Mokhtari \& Reichard, 2002 , p. 252). For instance, readers are more attentive to what they are reading, pause to verify their understanding, read again and again until they get the meaning, visualize the information, read out loud, or use their guessing skill when they do not know the vocabulary (Songsiengchai, 2010). Therefore, readers who use these strategies know what to do when they do not understand what they are reading by practicing effective ways that allow them to overcome these problems.

\subsubsection{Supporting Reading Strategies}

Supporting reading strategies are defined as basic support mechanism such as taking notes, intended to aid the readers in [to] comprehend the texts" (Mokhtari \& Sheorey, 2002, p. 4). Songsiengchai (2010) further stated that readers used supporting reading strategies while reading such as checking a dictionary, underlining important points, translating from English into their own languages and other outside supportive materials to comprehend their English reading texts. Therefore, supporting reading strategies take place when readers seek for an outside help/aid or individual practical techniques while reading English academic texts to improve their reading comprehension.

\subsection{Reading Engagement}

Educational researchers on students' engagement have been conducted into how to engage students in their learning. According to Furrer and Skinner (2003), engagement is an active, goal directed, flexible, constructive, persistent, focused interactions with the social and physical environments. Later on, Guthrie, Wigfield, Barbosa, Perencevich, Taboada, Davis, and Tonks (2004) divided the meaning of engagement into two parts: i) time on task (e.g. paying attention to text, concentrating on text meaning, and sustaining cognitive effort) and ii) affect surrounding engagement (e.g. interacting with external environments). Furthermore, engagement is a multidimensional phenomenon that involves students' emotion (reaction/attitude), behavior (participation/on-task behavior), and cognition (ideas of investment/selfregulation) (Fredricks, Blumenfeld, \& Paris, 2004). Student engagement is considered an important predictor of student's achievement. Therefore students who are engaged are good learners (Handelsman, Briggs, Sullivan, \& Towler, 2005).

Reading engagement includes four aspects: behavioral, emotional, cognitive, (Fredricks, Blumenfeld, \& Paris, 2004), and agentic (Reeve, 2012; Reeve, 2013; Reeve \& Tseng, 2011). In this study, reading engagement has a strong relationship to reading strategies and reading comprehension. Wigfield et al. (2008) discussed that highly engaged students used more reading strategies to comprehend texts than less engaged students because they 
were more motivated and strategic. Therefore, reading engagement has a strong correlation with reading comprehension through the employment of reading strategies.

\subsubsection{Agentic Engagement}

Agentic engagement is defined as "a newly proposed student-initiated pathway to greater achievement and greater motivational support" (Reeve, 2013, p.579). It refers to students' proactive, intentional, and constructive contribution to the flow of instruction or learning activities such as asking questions, making suggestions, expressing preferences, and seeking clarification (Christenson, Reschly, \& Wylie, 2012; Reeve \& Tseng, 2011). Agentic engagement involves students having more opportunities to enlarge their freedom of action, feeling strong motivation (e.g., autonomy, self-efficacy) and meaningful learning (e.g., internalization, conceptual understanding) (Bandura, 2006). Students become more active by coming up with ideas to create something new in class, provide input, and make positive changes that make their learning more achievable.

\subsection{2 . Behavioral Engagement}

Students who have behavioral engagement show their on-task attention and concentration, high effort and high task persistence in class (Christenson, Reschly, \& Wylie, 2012). According to Fredricks, Blumenfeld, and Paris (2004), behavioral engagement is related to "student conduct and on-task behavior" or "the idea of participation", which leads to academic achievement (p. 60). Lester (2013) further explained that students who had positive conduct commitments, involved with learning and participated in school activities, had positive learning performances. In brief, students who show good behavior in their learning engagement are committed to learning. In reading perspective, Guthrie and Klauda (2015) argued that readers who had strong "intrinsic motivation and self-efficacy" had strong behavioral engagement, which means that readers became "more enthusiastic, confident, and cognitively sophisticated" when they had strong personal interest, commitment, attention and self-belief in their reading tasks (p. 5). Lane and Harris (2015) showed that engaged readers who had positive behavior read different reading materials related to class, kept their eyes focused on and followed the reading materials in class, prepared printed notes, etc.

\subsubsection{Emotional Engagement}

Lester (2013) found that emotional engagement had three main components: students' affective reactions (e.g., student interest, boredom, anxiety, sadness, and happiness), emotional reactions (e.g., positive or negative feelings for the institution and instructors), and school identification (e.g., students' feelings of belonging and importance within the institutional environment). Emotional engagement refers to the feeling of belonging to the school, giving values of learning and showing pleasure for the classroom and afterschool activities (Christenson, Reschly, \& Wylie, 2012; Reeve \& Tseng, 2011). Thus, emotional engagement is related to learners' attitudes that express their positive/negative reactions and willingness to study based on their emotions (Fredricks, Blumenfeld, \& Paris, 2004). Park, Holloway, Arendtsz, Bempechat, and Li (2012) indicated that "adolescents' emotional engagement played a critical role in promoting their academic performance as well as overall psychological well-being" (p.390). Similarly, Artino and Jones (2012) found that enjoyment, boredom, and frustration were achievement-related emotions that were overriding predictors of students' learning, selfregulation and achievement. In contrast, students who do not feel emotionally engaged in their studies do not feel behaviorally and cognitively engaged; consequently, they have poor academic outcomes (Archambault, Janosz, Fallu, \& Pagani, 2009; Hirschfield \& Gasper, 2011). Moreover, low emotional engagement leads students to drop out due to their negative emotions and social difficulties with teachers and schools (Fredricks, Blumenfeld, \& Paris, 2004). Therefore, in class, learning materials should be interesting (e.g., group work, presentation, video clips, etc.) and school activities should help students to learn and relax at the same time (e.g., field trips, dance and song festival, student clubs, etc.).

\subsubsection{Cognitive Engagement}

According to Christenson Reschly, and Wylie (2012), cognitive engagement was defined as learners' knowledge of and belief in learning activities such as self-evaluation, self-regulation and self-perception of competence/ motivation, all of which are linked to academic achievement and participation. Fredricks, Blumenfeld, and Paris (2004) argued that cognitive engagement had two definitions: i) investment in learning (e.g., student effort in learning and problem solving) and ii) self-regulation, or being strategic (e.g., student learning strategies). In reading, cognitively engaged readers engage in high-level thinking about their reading texts, use word-recognition and reading comprehension strategies, and actively involve in reading activities, which relate to metacognitive thinking and schema knowledge (Taylor, Pearson, Peterson, \& Rodriguez, 2003). To measure cognitive reading engagement, McElhone (2012) used Mokhtari and Reichard's (2002) Metacognitive Awareness of Reading 
Strategies Inventory (MARSI), in which cognitively engaged readers frequently applied metacognitive reading strategies (global reading, problem solving and support reading strategies) while reading English academic texts. In this view, readers who have cognitive engagement use appropriate reading strategies that are suitable for improving their reading comprehension and to solve problems while reading texts.

\section{Theoretical Framework}

To support the study of metacognitive reading strategies, this study applied the Schema Theory as proposed by Bartlett (1932) that examined how people used prior knowledge and experiences to recall memories (Cook, 1997). This study also applied self-determination theory (SDT), which is the comprehensive intrinsic motivation to identify engagement function (Appleton, Christenson, \& Furlong, 2008; Reeve, 2012).

\subsection{Schema Theory}

This paper utilizes theoretical explanations about the relationship between schema theory, reading strategies, and reading comprehension conducted by previous researchers. Schema is background knowledge stored in readers' longterm memory (Gilakjani \& Ahmadi, 2011). Anderson and Pearson (1984) discovered “a reader's schemata, or knowledge already stored in memory, function in the process of interpreting new information and allowing it to enter and become a part of the knowledge store" (p. 255). According to Cook (1997), schema theory "was proposed by the gestalt psychologist Bartlett (1932) who observed how people, when asked to repeat a story from memory, filled in details which did not occur in the original but conformed to their cultural norms" (p. 86). Carrell and Eisterhold (1983) defined this theory as "a reader-centered, psycholinguistic processing model of EFL/ESL reading" that involved the combination of readers' background knowledge and reading texts in reading comprehension (p. 554). Carrell, Devine, and Eskey (1988) found three distinct dimensions of schema that strongly interacted among readers and texts: "linguistic" schema (prior language knowledge), "content" schema (knowledge of the topic), and "formal" schema (previous knowledge of the rhetorical structures of different types of texts)" (p. 4). Anderson and Pearson (1984) argued that readers lacking schema would have difficulties in comprehending the texts. Therefore, schema theory helps readers merge their background knowledge with reading texts and apply reading strategies to enhance their reading comprehension.

\subsection{Self-determination Theory}

Another theoretical framework of student reading engagement is self-determination theory (SDT). Appleton, Christenson, and Furlong (2008) believed that SDT provided "an important and comprehensive theoretical framework that helped clarify the functioning of the student engagement construct" (p. 378). According to Reeve (2012), SDT is a "theory of motivation" that was introduced 40 years ago by researchers to understand and improve students' engagement and learning achievement (p. 150). Wigfield et al. (2008) believed that "highly engaged readers were internally motivated to read" (p. 443). Furthermore, in SDT, intrinsic motivation and self-efficacy generate behavioral engagement in learning and reading (Guthrie \& Klauda, 2014). For example, if learners have "personal interest (intrinsic motivation) and believe in their capacity (self-efficacy), their behavioral engagement becomes more enthusiastic, confident, and cognitively sophisticated" (Guthrie \& Klauda, 2015. p. 5), which helps learners improve their learning performance. Additionally, Nie and Lau (2009) indicated that SDT helped researchers and teachers consider students' engagement and psychological well-being as key indicators of effective classroom management. In responding to students' psychological needs and engagement, SDT helps ensure that students are emotionally engaged in their learning (Park, Holloway, Arendtsz, Bempechat, \& Li, 2012). From this perspective, Reeve (2012) determined that SDT indicated how learners used their inner resources in a classroom environment that had possible effects on students' engagement.

\section{Hypothesis Development}

To test the hypotheses, the research framework was designed to investigate the effects of metacognitive reading strategies on reading engagement. Guthrie, Alao, and Rinehart (1997) argued that "engaged readers possessed desires to learn and used their best strategies for understanding and interpreting text to enhance that learning" (p. 439). Wigfield et al. (2008) found that engagement in reading had significant effects on reading strategies and understanding (p. 443). Previous studies examined the effects of metacognitive reading strategies on cognitive engagement in reading (Park \& Kim, 2016). McElhone (2012) also argued that students' use of metacognitive reading strategies represented students' cognitive reading engagement, which improved their understanding of what they were reading. However, previous studies rarely found any effect of metacognitive reading strategies on other types besides cognitive reading engagement. Therefore, this study hypothesized the effects of metacognitive reading 
strategies with categories of global reading, problem solving, and supporting reading strategies on agentic (H1a c), behavioral $(\mathrm{H} 2 \mathrm{a} \sim \mathrm{c})$, emotional $(\mathrm{H} 3 \mathrm{a} \sim \mathrm{c})$, and cognitive $(\mathrm{H} 4 \mathrm{a} \sim \mathrm{c})$ reading engagements. This study hypothesized "a" for global reading, " $b$ " for problem solving, and "c" for supporting reading strategies.

H1a c: Metacognitive reading strategies affect student agentic reading engagement while reading English academic texts.

H2a c: Metacognitive reading strategies affect student behavioral reading engagement while reading English academic texts.

H3a c: Metacognitive reading strategies affect student emotional reading engagement while reading English academic texts.

H4a c: Metacognitive reading strategies affect student cognitive reading engagement while reading English academic texts.

\section{Methodology}

This study collected data from universities in global academic environments where students were from diverse regions such as Asia, Africa, Europe, and America. All classes were taught in English, as this study measures the effects of reading English texts for academic purposes. All class materials were also provided and prepared in English. This study collected data both online and offline. 146 students completed the survey with a response rate of 85.9 percent.

This study applied the Metacognitive-Awareness-ofReading-Strategies Inventory (MARSI), which was originally developed by Mokhtari, Survey of Reading Strategies (SORS), which was extended by Mokhtari and Sheorey (2002), and reading engagements, which were developed by Reeve and Tseng (2011). Likert scales (5point scale) were applied, where $1=$ strongly disagree and 5 = strongly agree. This study measured Cronbach's alpha to test the reliability of the variables. Cronbach's alpha for global reading and problem-solving strategies were 0.67 , Cronbach's alpha for support reading strategies was 0.63 , Cronbach's alpha for agentic engagement was 0.84, Cronbach's alpha for behavioral engagement was 0.75 , Cronbach's alpha for emotional engagement was 0.69 , and Cronbach's alpha for cognitive engagement was 0.72 .

\section{Data Analysis}

Of the 146 respondents, $56.85 \%$ were male and $43.15 \%$ were female. $0.14 \%$ were $19-25$ years old, $0.30 \%$ were 26 -
29 years old, $0.23 \%$ were $30-35$ years old, $0.13 \%$ were 36 40 years old, and $0.20 \%$ were 40 years or older. $4.64 \%$ of the respondents spoke English as the first language, 53.64\% spoke English as the second language, $13.25 \%$ spoke English as their third language, and $28.48 \%$ spoke English as their fourth language.

This study applied factor analysis to check the validity of the variables, using principal component analyses as the extraction method and Varimax rotation methods with Kaiser Normalization. The results of the factor analysis represented the major constructs with Eigen values greater than 1.00. In order to test the hypotheses, regression analysis was conducted by using factor scores. The results of the regression analysis for the effects of metacognitive reading strategies such as global reading, problem-solving and supporting reading strategies on reading engagement (agentic, behavioral, emotional and cognitive engagement) while students were reading English for academic purposes were determined. Results of the ANOVA for the effects of metacognitive reading strategies on agentic engagement showed significant with $\mathrm{F}=6.614(\mathrm{R} 2=0.123)$.

Results of the ANOVA for the effects of metacognitive reading strategies on agentic engagement showed significant with $\mathrm{F}=6.614(\mathrm{R} 2=0.123)$. As shown in Table 1, H1a and H1c were accepted at the 0.01 and 0.05 levels, while $\mathrm{H} 1 \mathrm{~b}$ was rejected. The effects of global reading strategy on agentic engagement implied that when students had clear purposes for reading, they asked questions while reading in English or told teachers what they expected to learn from English reading tasks or what they were interested in reading.

Table 1: Effects of Metacognitive Reading Strategies on Agentic Engagement

\begin{tabular}{|c|c|}
\hline Variables & $\begin{array}{l}\text { Standardized Coeffi } \\
\text { cients (Sig) }\end{array}$ \\
\hline $\begin{array}{c}\text { Global Reading Strategy } \rightarrow \text { Agentic } \\
\qquad(\mathrm{H} 1 \mathrm{a})\end{array}$ & $.247\left({ }^{* * *}\right)$ \\
\hline $\begin{array}{l}\text { Problem Solving Strategy } \rightarrow \text { Agentic } \\
\qquad(\mathrm{H} 1 \mathrm{~b})\end{array}$ & -.068 \\
\hline $\begin{array}{c}\text { Supporting Reading Strategy } \rightarrow \text { Age } \\
\text { ntic }(\mathrm{H} 1 \mathrm{c})\end{array}$ & $.202\left({ }^{\star \star}\right)$ \\
\hline
\end{tabular}

*** Significant at 0.01 level (2-tailed);

** Significant at 0.05 level (2-tailed).

Results of the ANOVA for the effects of metacognitive reading strategies on behavioral engagement showed significant with $F=7.228\left(\mathrm{R}^{2}=0.132\right)$. As shown in Table 2, $\mathrm{H} 2 \mathrm{a}$ and $\mathrm{H} 2 \mathrm{c}$ were accepted at the 0.01 and 0.05 levels, while $\mathrm{H} 2 \mathrm{~b}$ was rejected. The effects of global reading strategy on behavioral engagement implied that when students had a clear purpose and intentional plan for 
reading, they paid attention, tried hard, and listened carefully during reading in class.

Table 2: Effects of Metacognitive Reading Strategies on Behavioral Engagement

\begin{tabular}{|l|c|}
\hline \multicolumn{1}{|c|}{ Variables } & $\begin{array}{c}\text { Standardized } \\
\text { Coefficients (Sig) }\end{array}$ \\
\hline $\begin{array}{l}\text { Global Reading Strategy } \rightarrow \\
\text { Behavioral (H2-1) }\end{array}$ & $.231\left(^{* * *}\right)$ \\
\hline $\begin{array}{l}\text { Problem Solving Strategy } \rightarrow \\
\text { Behavioral (H2-2) }\end{array}$ & .057 \\
\hline $\begin{array}{l}\text { Supporting Reading Strategy } \rightarrow \\
\text { Behavioral (H2-3) }\end{array}$ & $.177\left(^{* *}\right)$ \\
\hline
\end{tabular}

*** Significant at 0.01 level (2-tailed);

** Significant at 0.05 level (2-tailed).

Table 3: The Effects of Metacognitive Reading Strategies on Emotional Engagement

\begin{tabular}{|c|c|}
\hline$\underset{\text { Variables }}{\text { (Independent }} \rightarrow$ Depende & $\begin{array}{l}\text { Standardized Coeff } \\
\text { icients (Sig) }\end{array}$ \\
\hline $\begin{array}{c}\text { Global Reading Strategy } \rightarrow \text { Emotiona } \\
\qquad \mathrm{I}(\mathrm{H} 3-1)\end{array}$ & $\left..3011^{(* \star}\right)$ \\
\hline $\begin{array}{c}\text { Problem Solving Strategy } \rightarrow \text { Emotion } \\
\text { al (H3-2) }\end{array}$ & .074 \\
\hline $\begin{array}{c}\text { Supporting Reading Strategy } \rightarrow \text { Emot } \\
\text { ional }(\mathrm{H} 3-3)\end{array}$ & .092 \\
\hline
\end{tabular}

*** Significant at 0.01 level (2-tailed).

Results of the ANOVA for the effects of metacognitive reading strategies on emotional engagement showed significant with $F=7.859\left(\mathrm{R}^{2}=0.142\right)$. As shown in Table 3 , H3a was accepted at the 0.01 and 0.05 levels, while $\mathrm{H} 3 \mathrm{~b}$ and $\mathrm{H} 3 \mathrm{c}$ were rejected. The effects of global reading strategies on emotional engagement implied that when students read the English academic texts that met their purposes and understood before moving to the new section of the reading texts, they felt that they enjoyed reading and were curious about their reading tasks.

Results of the ANOVA for the effects of metacognitive reading strategies on cognitive engagement showed significant with $F=11.827\left(\mathrm{R}^{2}=0.200\right)$. As shown in Table 4, H4a and H4b were accepted at the 0.01 and 0.1 levels, while $\mathrm{H} 4 \mathrm{c}$ was rejected. The effects of global reading strategies on cognitive engagement implied that when students had careful and clear purposes of reading and understood clearly before moving to the next part of the reading texts, students had good understanding of their reading task by using personal reading strategies rather than following others.

Additionally, this study conducted ANOVA based on respondents' characteristics. Among engagements, the results showed that the means of questionnaire items for agentic engagements differ based on age groups. The results also showed that the means of global reading strategies differ based on categories based on the number of hours spent reading English academic texts each day.

Table 4: The Effects of Metacognitive Reading Strategies on Cognitive Engagement

\begin{tabular}{|c|c|}
\hline $\begin{array}{c}\text { Variables (Independent } \rightarrow \text { Depe } \\
\text { ndent) }\end{array}$ & $\begin{array}{c}\text { Standardized Coefficie } \\
\text { nts (Sig) }\end{array}$ \\
\hline $\begin{array}{c}\text { Global Reading Strategy } \rightarrow \text { Cogn } \\
\text { itive (H4a) }\end{array}$ & $.300\left(^{* * *}\right)$ \\
\hline $\begin{array}{c}\text { Problem Solving Strategy } \rightarrow \text { Cog } \\
\text { nitive (H4b) }\end{array}$ & $.159\left(^{*}\right)$ \\
\hline $\begin{array}{c}\text { Supporting Reading Strategy } \rightarrow \\
\text { Cognitive (H4c) }\end{array}$ & .125 \\
*** Significant at 0.01 level (2-tailed); \\
* Significant at 0.1 level (2-tailed).
\end{tabular}

\section{Conclusion}

\subsection{Findings}

This study aimed to investigate the effects of metacognitive reading strategies on reading engagement in higher education and also in global academic environment. The results found that the effects of global reading strategies showed significant on four aspects of reading engagement including agentic, behavioral, emotional, and cognitive. The effects of supporting reading strategies showed significant on agentic and behavioral reading engagements. The effects of problem-solving strategies showed significant on cognitive reading engagement.

The effects of supporting reading strategies on agentic engagement implied that how do students underlined, took notes or checked meanings while reading English academic texts affect how they understood what they were reading and enabled them to express more opinions or make contributions in class. The effects of problem solving strategies for agentic engagement implied that student might not apply problem-solving strategies to improve their agentic engagement, while they applied those strategies to solve reading problems in order to comprehend what they were reading. The effect of supporting reading strategies on behavioral engagement implied that how students took notes and checked the dictionary affected how they understood the English texts and had ideas to discuss with other students. The effects of problem solving strategies on behavioral engagement implied that how students found difficulties in reading affect how they used reading techniques such as reading repeatedly, reading slowly, guessing the meanings of words to improve their understanding rather than encouraging themselves to 
actively participate with others such as in group discussion while reading English academic texts (behavioral engagement).

The effects of global reading strategies on emotional engagement implied that how students read to confirm their understanding before moving on to a new section of their reading texts affect how they felt that they enjoyed reading and were curious about their reading tasks. The effects of problem solving strategies on emotional engagement showed that how students tried to solve the problems and used outside aids to overcome their reading difficulties affected emotional reading engagement was not supported. The effects of global reading and problem solving strategies on cognitive engagement implied that students who had a clear intention and purpose for reading and knew how to overcome reading challenges when the texts became difficult had better understanding of their reading texts by using own personal reading strategies rather than following others. The effects of supporting reading strategy on cognitive engagement implied that students might think that using supportive reading strategies might not the best way to improve their understanding of English academic texts.

Metacognitive reading strategies and reading engagement play important roles in reading skills by improving student learning outcomes. In order to apply metacognitive strategies in reading, readers need to develop self-management skills. According to Jacobs and Paris (1987), readers who have self-management of thinking have strategic planning (e.g., having a reading purpose), strategic evaluation (e.g., checking their understanding) and regulation strategies (e.g., monitoring their reading progress and revising their planning after evaluation). This implies that readers who have better self-management skills tend to apply more metacognitive reading strategies while reading academic texts in English. As these results showed, the effects of global reading and problem-solving strategies were related to cognitive engagement, described as readers' knowledge and beliefs about reading activities and themselves such as self-evaluation, self-regulation and selfperception of competence or motivation, which in turn was linked to academic achievement and participation (Christenson, Reschly, \& Wylie, 2012). Self-managed readers employ "metacognitive self-regulation strategies such as planning, monitoring, and revising one's work" that help them seek conceptual understanding rather than surface knowledge (Reeve \& Tseng, 2011, p. 4). These processes encourage readers to implement reading strategies not only while they are reading, but also require them to practice again and again, which improves their long-term understanding. Therefore, enabling selfmanagement in metacognitive reading strategies helps readers improve their cognitive engagement and reading comprehension both in the long and the short term.

\subsection{Managerial Implications}

This study provides implications for students, teachers, and other stakeholders in the field of education. The purpose of this research is to provide some reading strategies not only to students, but also to instructors of developmental reading courses and other educators to improve reading skills. Madhumathi and Ghosh (2012) argued that reading plays a significant role in education, while reading skills are considered as one of the most challenging skills to acquire (Amin, 2019). Many EFL/ESL readers struggle with reading English academic texts due to their limited English language and reading proficiencies (Grabe \& Zhang, 2013). The first reason that readers have difficulties in reading is because they do not know effective reading strategies (Nezami, 2012). Second, many students have low reading engagement (Brozo, Shiel, \& Topping, 2007). Therefore, this study suggests that students can apply metacognitive reading strategies that have positive effects on their reading engagement and comprehension. This study also implies that it is necessary to promote metacognitive reading strategies and improve reading engagement in order to enhance reading skills. Therefore, several managerial implications in education are recommended, including readers' awareness and improvements, as well as teachers' application of metacognitive reading strategies. This study provides managerial implications with advanced technology. Utilization of Learning Management system (LMS) by adopting advanced technology (Ramli, Darus, \& Bakar, 2011) will help improve reading strategies. Managing online learning with advanced technology (Ramli, Darus, \& Bakar, 2011) will also help increase interactivity particularly in global environment. This study also provide managerial implications in higher education by providing better strategies to enhance learning skills in global context. In particular, the results of this study indicated how the effects of problem solving and supporting strategies could be improved. This study provides implications that applying better management systems and techniques help enhance academic effects in globalized education.

\subsection{Limitations}

This study has some limitations. The sample size should be increased in future studies. Future studies might consider comparative analysis of different metacognitive reading strategy usages by comparing native and non-native English-speaking readers in order to improve their reading engagement. This will be helpful for students to know what metacognitive reading strategies are appropriate for them as native English speakers or EFL/ESL readers. Furthermore, it will enable teachers who teach students from different 
countries to know suitable reading strategies needed to engage students in reading tasks. Comparative studies of metacognitive reading strategies used by low and high English reading proficiency readers to improve reading engagement could be considered.

\section{References}

Alderson, J. C. (2000). Assessing Reading. Cambridge, England: Cambridge University Press.

Alfassi, M. (2004). Reading to Learn: Effects of Combined Strategy Instruction on High School Students. The Journal of Educational Research, 97(4), 171-185.

Amin, M. (2019). Developing Reading Skills through Effective Reading Approaches. International Journal of Social Science and Humanities, 4(1), 35-40.

Anderson, R. C., \& Pearson, P. D. (1984). A Schema-theoretic View of Basic Processes in Reading Comprehension. Handbook of Reading Research, 1, 255-291.

Appleton, J. J., Christenson, S. L., \& Furlong, M. J. (2008). Student Engagement with School: Critical Conceptual and Methodological Issues of the Construct. Psychology in the Schools, 45(5), 369-386.

Archambault, I., Janosz, M., Fallu, J., \& Pagani, L. S. (2009). Student Engagement and Its Relationship with Early High School Dropout. Journal of Adolescence, 32(3), 651-670.

Artino, A. R. Jr., \& Jones II, K. D. (2012). Exploring the Complex Relations between Achievement Emotions and Self-regulated Learning Behaviors in Online Learning. The Internet and Higher Education, 15(3), 170-175.

Appleton, J. J., Christenson, S., \& Furlong, M. J. (2008). Student Engagement with School: Critical Conceptual and Methodological Issues of the Construct. Psychology in the Schools, 45(5), 369-386.

Aydoğan, H., \& Akbarov, A. A. (2014). The Four Basic Language Skills, Whole Language \& Intergrated Skill Approach in Mainstream University Classrooms in Turkey. Mediterranean Journal of Social Sciences, 5(9), 672.

Bandura, A. (2006). Toward a Psychology of Human Agency. Perspectives on Psychological Science, 1(2), 164-180.

Bartlett, F. C. (1932). Remembering: A Study in Experimental and Social Psychology. Cambridge, England: Cambridge University Press.

Brozo, W. G., Shiel, G., \& Topping, K. (2007). Engagement in Reading: Lessons Learned from Three PISA Countries. Journal of Adolescent \& Adult Literacy, 51(4), 304-315.

Carrell, P. L., \& Eisterhold, J. C. (1983). Schema Theory and ESL Reading Pedagogy. TESOL quarterly, 17(4), 553-573.

Carrell, P. L., \& Eskey, D. E. (1988). Interactive Approaches to Second Language Reading. Cambridge, England: Cambridge University Press.

Carrell, P. L., Pharis, B. G., \& Liberto, J. C. (1989). Metacognitive Strategy Training for ESL Reading. Tesol Quarterly, 23(4), 647-678.

Christenson, S. L., Reschly, A. L., \& Wylie, C. (2012). Handbook of Research on Student Engagement (Eds.). New York, NY: Springer Science \& Business Media.
Cook, G. (1997). Schemas. ELT Journal, 51(1), 86-86.

Farahian, M., \& Farshid, M. (2014). A Reader-Response Approach to Reading: Does It Have an Effect on Metacognitive Reading Strategies? Modern Journal of Language Teaching Methods, 4(1), 371.

Fredricks, J. A., Blumenfeld, P. C., \& Paris, A. H. (2004). School Engagement: Potential of the Concept, State of the Evidence. Review of Educational Research, 74(1), 59-109.

Furrer, C., \& Skinner, E. (2003). Sense of Relatedness as a Factor in Children's Academic Engagement and Performance. Journal of Educational Psychology, 95(1), 148-162.

Grabe, W., \& Zhang, C. (2013). Second Language Readingwriting Relations. In A. S. Horning \& E. W. Kraemer (eds), Reconnecting Reading \& Writing (p.108-133).

Gilakjani, A. P., \& Ahmadi, S. M. (2011). The Relationship between L2 Reading Comprehension and Schema Theory: A Matter of Text Familiarity. International Journal of Information and Education Technology, 1(2), 142-149.

Guthrie, J. T., Alao, S., \& Rinehart, J. M. (1997). Literacy issues in focus Engagement in reading for young adolescents. Journal of Adolescent \& Adult Literacy, 40(6), 438-446.

Guthrie, J. T., Wigfield, A., Barbosa, P., Perencevich, K. C., Taboada, A., Davis, M. H., \& Tonks, S. (2004). Increasing Reading Comprehension and Engagement through ConceptOriented Reading Instruction. Journal of Educational Psychology, 96(3), 403-423.

Guthrie, J. T., \& Klauda, S. L. (2014). Effects of Classroom Practices on Reading Comprehension, Engagement, and Motivations for Adolescents. Reading Research Quarterly, 49(4), 387-416.

Guthrie, J. T., \& Klauda, S. L. (2015). Engagement and Motivational Processes in Reading. Handbook of Individual Differences in Reading: Reader, Text and Context, 41-53.

Hamza, A., \& Nur, S. B. I. (2018), Reading Comprehension Strategies among EFL Learners in Higher Learning Institutions. Arab World English Journal, 9(2), 315-328.

Handelsman, M. M., Briggs, W. L., Sullivan, N., \& Towler, A. (2005). A Measure of College Student Course Engagement. The Journal of Educational Research, 98(3), 184-192.

Hirschfield, P. J., \& Gasper, J. (2011). The Relationship between School Engagement and Delinquency in Late Childhood and Early Adolescence. Journal of Youth and Adolescence, 40(1), 3-22.

Ilustre, C. A. (2011). Beliefs about Reading, Metacognitive Reading Strategies and Text Comprehension among College Students in a Private University. Philippine ESL Journal, 7, 28-47.

Jacobs, J. E., \& Paris, S. G. (1987). Children's Metacognition about Reading: Issues in Definition, Measurement, and Instruction. Educational Psychologist, 22(3-4), 255-278.

Kahn, H. E., \& Agnew, M. (2017). Global Learning Through Difference: Considerations for Teaching, Learning, and the Internationalization of Higher Education. Journal of Studies in International Education, 21(1), 52-64.

Karbalaei, A. (2010). A Comparison of the Metacognitive Reading Strategies Used by EFL and ESL Readers. The Reading Matrix, 10(2), 165-180.

Lane, E. S., \& Harris, S. E. (2015). A New Tool for Measuring Student Behavioral Engagement in Large University Classes. 
Journal of College Science Teaching, 44(6), 83-91.

Lester, D. (2013). A Review of the Student Engagement Literature. FOCUS on Colleges, Universities \& Schools, 7(1), 1-8.

Madhumathi, P., \& Ghosh, A. (2012). Awareness of Reading Strategy Use of Indian ESL Students and the Relationship with Reading Comprehension Achievement. English Learning Teaching, 5(12), 131-140.

McElhone, D. (2012). Tell Us More: Reading Comprehension, Engagement, and Conceptual Press Discourse. Reading Psychology, 33(6), 525-561.

Meniado, J. C. (2016). Metacognitive Reading Strategies, Motivation, and Reading Comprehension Performance of Saudi EFL Students. English Language Teaching, 9(3), 117129.

Mokhtari, K., \& Sheorey, R. (2002). Measuring ESL Students' Awareness of Reading Strategies. Journal of Developmental Education, 25(3), 2-11.

Mokhtari, K., \& Reichard, C. (2004). Investigating the Strategic Reading Processes of First and Second Language Readers in Two Different Cultural Contexts. System, 32(3), 379-394.

Mukhlif, Z., \& Amir, Z. (2017). Investigating the Metacognitive Online Reading Strategies employed by Iraqi EFL Undergraduate Students. Arab World English Journal (AWEJ), $8(1), 372-385$.

Nezami, S. R. A. (2012). A Critical Study of Comprehension Strategies and General Problems in Reading Skill Faced by Arab EFL Learners with Special Reference to Najran University in Saudi Arabia. International Journal of Social Sciences \& Education, 2(3), 306-316.

Nie, Y., \& Lau, S. (2009). Complementary Roles of Care and Behavioral Control in Classroom Management: The Selfdetermination Theory Perspective. Contemporary Educational Psychology, 34(3), 185-194.

Park, S., Holloway, S. D., Arendtsz, A., Bempechat, J., \& Li, J. (2012). What Makes Students Engaged in Learning? A TimeUse Study of Within-and Between-Individual Predictors of Emotional Engagement in Low-Performing High Schools. Journal of Youth and Adolescence, 41(3), 390-401.

Park, S. W., \& Kim, C. (2016). The Effects of a Virtual Tutee System on Academic Reading Engagement in a College Classroom. Educational Technology Research and Development, 64(2), 195-218.

Papleontiou-louca, E. (2003). The Concept and Instruction of
Metacognition. Teacher Development, 7(1), 9-30.

Pinninti, L. (2016). Metacognitive Awareness of Reading Strategies: An Indian Context. The Reading Matrix: An International Online, 16(1), 179-193.

Pookcharoen, S. (2009). Metacognitive Online Reading Strategies among Thai EFL University Students (Dissertation). Indiana University, Bloomington, Indiana.

Ramli, N. F. M., Darus, S., \& Bakar, N. A. (2011). Metacognitive Online Reading Strategies of Adult ESL Learners Using a Learning Management System. Theory and Practice in Language Studies, 1(3), 195-204.

Reeve, J., \& Tseng, C. M. (2011). Agency as a Fourth Aspect of Students' Engagement during Learning Activities. Contemporary Educational Psychology, 36(4), 257-267.

Reeve, J. (2012). A Self-determination Theory Perspective on Student Engagement. In Handbook of Research on Student Engagement, Boston, MA: Springer, 149-172.

Reeve, J. (2013). How Students Create Motivationally Supportive Learning Environments for Themselves: The Concept of Agentic Engagement. Journal of Educational Psychology, 105(3), 579-595.

Seidlhofer, B. (2005). English as a Lingua Franca. ELT Journal, 59(4), 339-341.

Shehadeh, A. (2016). Reading Strategies Used by Palestinian College Students. Arab World English Journal, 6(4), 15-25.

Sheorey, R., \& Mokhtari, K. (2001). Differences in the Metacognitive Awareness of Reading Strategies among Native and Non-native Readers. System, 29(4), 431-449.

Songsiengchai, T. (2010). Strategies in Reading Online and Printed Academic Texts of English Major Students of Srinakharinwirot University (Master's Thesis). Srinakharinwirot University, Bangkok, Thailand.

Taylor, B. M., Pearson, P. D., Peterson, D. S., \& Rodriguez, M. C. (2003). Reading Growth in High-poverty Classrooms: The Influence of Teacher Practices that Encourage Cognitive Engagement in Literacy Learning. The Elementary School Journal, 104(1), 3-28.

Wigfield, A., Guthrie, J. T., Perencevich, K. C., Taboada, A., Klauda, S. L., McRae, A., \& Barbosa, P. (2008). Role of Reading Engagement in Mediating Effects of Reading Comprehension Instruction on Reading Outcomes. Psychology in the Schools, 45(5), 432-445. 